\title{
SIGILOS CONSTITUCIONAIS, PROVA ILÍCITA E PROPORCIONALIDADE
}

\author{
Elmir Duclerc ${ }^{1}$
}

\begin{abstract}
RESUMO
Doutrina e jurisprudência dominantes, de um modo geral, entendem cabível a quebra do sigilo de dados e da correspondência, a despeito do que dispõe o art. 5ㅜㅡ. XII, da CF. O argumento normalmente utilizado para tanto é recolhido da doutrina dos direitos fundamentais, segundo a qual não existe direito fundamental absoluto, de forma que a, a depender das circunstâncias, tendo em vista a natureza dos interesses em conflito, podem sofrer restrições, desde que haja previsão legal para tanto, e autorização judicial. No caso do sigilo da correspondência, entretanto, nem mesmo esse argumento acode a quebra do sigilo, já que não existe previsão legal expressa nesse sentido. $\mathrm{O}$ argumento parece ignorar, ainda, que a própria garantia da vedação às provas ilícitas é o produto de uma ponderação do próprio constituinte entre o direito do Estado de investigar crimes e outros valores que a própria ordem constitucional protege, tal como a intimidade e a vida privada do indivíduo. Além disso, ao propor a ponderação entre a intimidade e o bem jurídico supostamente violado pelo acusado na prática delitiva, viola-se o princípio da presunção ou estado de inocência. Condena-se antes, para considerar a prova lícita, e não o contrário, como impõe a noção ais elementar de devido processo legal. Por fim, tem-se uma segunda distorção do princípio da proporcionalidade, uma vez que os requisitos para a quebra de sigilos "absolutos" acabam bem mais "frouxos" do que aqueles estabelecidos para a quebra do sigilo telefônico.
\end{abstract}

PALAVRAS-CHAVE: Prova. Sigilo. Proporcionalidade.

\footnotetext{
1 Promotor de justiça criminal em Salvador e assessor especial criminal da Procuradoria Geral de Justiça da Bahia. Mestre em ciências criminais pela Universidade Cândido Mendes-RJ e doutor em direito pela Universidade Estácio de Sá-RJ. Professor Adjunto de Processo Penal da Universidade Federal da Bahia. Membro fundador e presidente do Instituto Baiano de Direito Processual Penal - IBADP.
} 


\begin{abstract}
Dominant doctrine and case law, in general, understand that is possible to violation of confidentiality of correspondence, in spite of what has art. 5th, XII of the Constitution. The argument that usually used for this point came from the doctrine of fundamental rights, according to which there is no absolute right, so that, depending on the circunstances, some rights may be restricted, provided there legal provision for this, and judicial authorization. In the case of the secrecy of correspondence, however, even this argument doesn't works for confidentiality, because there is no express legal provision accordingly. The argument seems to ignore also that the assurance of prohibition of the illegal evidence is the product of a balance between the right of the State to investigate crimes and other values that protects the constitutional order, as the intimacy and privacy. Moreover, by proposing a balance between intimacy and legal right infringed by the accused, violates the principle of presumption of innocence. Condemns before, to consider legal evidence, disobeying the due process of law. Finally, there is a second distortion of the principle of proportionality, because the requirements for the breaking of "absolute" secrets are revealed more "loose" than those established for the violation of telephone secrecy.
\end{abstract}

KEYWORDS: Evidence. Secrecy. Proportionality.

\title{
1 Introdução
}

Reza o art. 5º, XII, da CF que:

“[...] é inviolável o sigilo da correspondência e das comunicações telegráficas, de dados e das comunicações telefônicas, salvo, no último caso, por ordem judicial, nas hipóteses e na forma que a lei estabelecer para fins de investigação criminal ou instrução processual penal;"

Somente no ano de 1996, editou-se a Lei $\mathrm{n}^{-}$9.296/96, justamente para dar cumprimento ao comando constitucional, e regulamentar a quebra do sigilo telefônico.

Quanto aos demais sigilos, entretanto, a quebra segue sendo deferida e utilizada como meio de obtenção de prova, em que pese o sigilo não ter sido excepcionado pelo texto constitucional, tal como ocorreu com o sigilo telefônico.

O presente trabalho tem por objetivo enfrentar perplexidades como essa, além de outras questões correlatas, estudando criticamente a questão dos sigilos e propondo caminhos interpretativos alternativos ao que prevalece no senso comum teórico constituído tanto em doutrina quanto em jurisprudência. 


\section{Qual processo penal?}

Não se pode fazer ciência sem método. E o método científico exige a definição prévia de um "referencial teórico" mais ou menos consistente, que sirva de ponto de partida para qualquer investigação que se pretenda realizar sobre um determinado tema específico.

É preciso, portanto, dizer logo que buscamos falar de um processo penal que dialogue com outras áreas do saber humano, sobretudo o pensamento crítico em ciências sociais e, mais especificamente, com as contribuições da chamada criminologia crítica, ${ }^{2}$ que surge na década de 1970, como novo grande paradigma do pensamento criminológico moderno, em substituição à chamada criminologia tradicional ou etiológica.

A criminologia crítica, ${ }^{3}$ como se sabe, ao mesmo tempo que denuncia as fragilidades da criminologia tradicional, procura apoiar-se sobre o chamado paradigma da reação social, ou paradigma da definição, o que significa dizer que

“[...] a investigação criminológica tem a tendência a deslocar-se das causas do comportamento criminoso para as condições a partir das quais, em uma sociedade dada, as etiquetas de criminalidade e o status de criminoso são atribuídos a

2 Cabe, sem dúvida, a Kant, a paternidade do termo crítica, como o processo através do qual a razão empreende o conhecimento de si. ABBAGNANO, N. Dicionário de filosofia, p. 221. De lá pra cá, é lógico que o termo crítica tem dado azo a um sem número de definições e redefinições, de forma que seria absolutamente inimaginável, para os limites deste trabalho, dar conta de todas elas. Pode-se trabalhar, contudo, com a noção clara e simples formulada por Michel Miaille, que assinala: "É preciso tomar o termo em todo o seu sentido: o da possibilidade de fazer aparecer o invisível." (Introdução crítica ao direito, p. 21). Vale dizer, adotar uma postura crítica significa, no estudo de fatos sociais, a busca dos impensados sociais, das realidades que estão escondidas por trás dos discursos.

3 Por criminologia crítica, como bem salienta Baratta, entende-se um campo muito vasto e não homogêneo de discursos que, no campo do pensamento criminológico e sociológico jurídico contemporâneo, têm em comum uma característica que os distingue da criminologia tradicional: a nova forma de definir o objeto e os termos mesmos da questão criminal. (BARATTA, Alessandro. Criminologia crítica e crítica do direito penal: introdução à sociologia do direito penal. Tradução de Juarez Cirino dos Santos. Rio de Janeiro: Revan, 1997, p. 209). Na construção desse novo paradigma não se pode negar a forte influência do pensamento de Karl Marx. Coube a ele, como se sabe, formular pela primeira vez um discurso organizado denunciando a influência decisiva das relações econômicas travadas na sociedade (relações de dominação), na conformação dos demais fenômenos sociais (dentre os quais o Direito), que não seriam, aliás, mais que uma superestrutura da estrutura material econômica. Como bem registra Zaffaroni, "[...] embora Marx não tenha analisado em profundidade o sistema penal [...] considerava necessário deslegitimar todo o direito, especialmente o penal [...]" (ZAFFARONI, E. R. Em busca das penas perdidas, 1991). Daí que seu pensamento vai ser ponto de referência e fonte de inspiração, direta ou indiretamente, para toda a crítica do sistema penal que se lhe segue. Não se pode deixar de citar, de igual modo, a crítica radical de Foucault, M., denunciando, dentre outras coisas, o processo de construção das sociedades modernas capitalistas como resultante de um projeto de dominação amparado na noção de poder disciplinar (que implica uma relação genética e indissolúvel entre saber e poder), que tem como verdadeiro ponto de referência o modelo benthaniano (pan-óptico) de prisão. É o que se extrai de obras como Vigiar e punir (1999, 262 p.) e A verdade e as formas jurídicas, (1999, 160 p.). 
certos comportamentos e a certos sujeitos (labeling approach), assim como para o funcionamento da reação social informal e institucional". ${ }^{4}$

Trocando em miúdos, enquanto a criminologia tradicional pretende desenvolver uma teoria geral sobre as causas sociais do crime, a criminologia crítica está preocupada em descobrir por que, numa determinada sociedade, certos comportamentos e, sobretudo, certos grupos humanos são criminalizados, em detrimento de outros.

Em suma, criam-se condições para a crítica e a denúncia do próprio sistema penal como instrumento de dominação que se exerce mediante a criminalização de certas pessoas. O Direito Penal, portanto, funciona na medida em que disponibilize e legitime as formas mais violentas de intervenção estatal a serviço de grupos hegemônicos, em franca contradição comtodo e qualquer ideal democrático e socialista de justiça e igualdade.

A missão da criminologia crítica, portanto, confunde-se com a luta permanente pela descriminalização, isto é, a mais rigorosa redução possível do sistema penal. O próprio Direito Penal, nesse sentido, estaria reduzido a uma atitude de defesa. "Defesa, antes de tudo, do direito penal em face dos ataques realizados em nossos dias contra as garantias liberais asseguradas nas constituições dos Estados de Direito." ${ }^{5}$

A dogmática processual penal, nessa perspectiva, deve ser capaz de criar conceitos como jurisdição, processo, princípios, justamente para funcionarem como verdadeiros diques de segurança que controlem e evitem ao máximo a punição. Essa, segundo pensamos, é a lógica de uma dogmática crítica e garantista, que reconhece que precisa trabalhar com os elementos do sistema, mas compreende que, mesmo dentro desses limites, há um grande espaço de luta que nos permite manter viva a esperança de um direito processual penal mais humano e racional.

É nessa perspectiva que pretendemos estudar os chamados sigilos constitucionais previstos no art. 5ํㅗ XII, da CF.

\section{Direito à prova, verdade e sistemas processuais}

Em trabalhos anteriores ${ }^{6}$ já sustentamos a possibilidade de compreender prova como uma espécie de comunicação, como troca de mensagens entre emissores (partes, testemunhas, peritos) e receptor (o juiz), que deve receber, processar, interpretar e valorar os dados que lhe são transmitidos, como etapa necessária do processo decisório.

Essa definição de prova tem em seu favor, segundo entendemos, o fato de permitir uma certa conciliação entre conceitos como objeto, ônus, meio de prova, além de tornar compreensível o próprio conceito de elemento de prova, já que, por elemento pode-se

\footnotetext{
4 BARATTA, A. Op. cit., p. 210-211.

5 BARATTA, A. Op. cit., p. 221.

6 DUCLERC, Elmir. Prova penal e garantismo: uma investigação crítica sobre a verdade fática construída através do processo. Rio de Janeiro: Lumen Juris, 2004, p. 16.
} 
entender uma espécie de unidade que compõe, com outras, o chamado conjunto probatório de um determinado processo judicial de conhecimento. É claro que essa unidade nunca pode ser delimitada ou mensurada, ou seja, jamais será possível dizer que esse ou aquele elemento de prova começa aqui e termina alhures, ou que o conjunto probatório desse ou daquele processo é composto por tantos ou quantos elementos de prova. $\mathrm{Na}$ realidade, o conceito de elemento de prova traduz-se numa abstração que permite ao jurista compreender a prova como um conjunto, uma base de dados sobre o passado, construídos e transmitidos ao juiz através da linguagem.

Daí decorre que o tema da verdade processual (interpretação verdadeira do direito a ser aplicado a fatos verdadeiros) assume uma importância fundamental. Afinal, todas as demais garantias ficam completamente esvaziadas e assumem um papel puramente ideológico se, no sistema penal, o cidadão não tiver qualquer proteção contra o arbítrio judicial na identificação dos pressupostos fáticos da sanção penal.

É preciso ter em mente, contudo, que essa verdade processual, isto é, a verdade fática que se pretende construir através do processo, não tem e não poderia mesmo ter qualquer compromisso com o conceito vago, quase metafísico e absolutamente inatingível de verdade real. Trata-se, antes, de trazer para o processo penal a única forma aceitável, na ciência da atualidade, de se falar em verdade, isto é, num sentido meramente aproximativo.

Para demonstrar o que acabamos de afirmar, basta que estejamos atentos aos limites que tornam realmente impossível falar de verdade, no processo, senão nesses termos.

Tem-se primeiro que as proposições que compõem as argumentações judiciais, tanto fáticas quanto estritamente jurídicas, são insuscetíveis de verificação experimental direta, como as proposições empíricas de observação. Não podemos, por exemplo, repetir em laboratório o fato criminoso, para saber como ele de fato acontece; como ocorre com qualquer investigação histórica, a verdade dessas proposições pode ser enunciada somente pelos "efeitos" produzidos, quer dizer, "os sinais do passado (pastness), deixados no presente pelos eventos passados, dos quais aqueles descrevem a ocorrência". ${ }^{7}$

Qualquer conclusão a que se chegue, dessa forma, tem, portanto, o valor de uma hipótese apenas probabilística, pois um mesmo conjunto de observações e dados historiográficos pode, não raro, admitir diversas explicações. Em suma, por mais eloquentes que sejam os dados do passado deixados no presente (depoimentos de testemunhas, indícios materiais coletados e analisados por peritos, documentos etc.), absolutamente nada nos imuniza contra a possibilidade do erro judiciário.

Além disso, é preciso ter em mente a carga específica de subjetividade do conhecimento judicial. Ainda conforme a lição de Ferrajoli, a própria subjetividade do juiz está sujeita a uma espécie de deformação profissional que lhe impõe uma forma jurisdicizada de ver o mundo, que muitas vezes o impede de perceber certos detalhes, considerar certas variáveis. Além disso, o juiz se vê envolvido, no processo, com as subjetividades

FERRAJOLI, L. Direito e razão: teoria do garantismo penal, p. 44. 
dos outros atores processuais (testemunhas, peritos etc.), o que incrementa ainda mais as dificuldades na busca da verdade objetiva.

Parece claro, assim, que qualquer aspiração de alcançar uma verdade real milita contra a lógica já assimilada por praticamente todas as áreas do conhecimento humano, e, o que é mais grave, esconde por trás de si um discurso decisionista e, justo por isso, radicalmente autoritário.

Lamentavelmente, alguns setores da doutrina processual penal pátria ainda incluem a verdade real como um dos princípios do Direito Processual Penal, e chegam a apontá-lo, inclusive, como traço distintivo entre o processo penal e o processo civil. Assim, no processo não penal haveria uma preocupação com um conceito meramente formal de verdade, que seria consequência, não poucas vezes, apenas de alguns atos ou fatos processuais. Assim, se o réu não contesta a inicial no prazo, diz a Lei que os fatos narrados pelo autor devem ser tidos como verdadeiros (art. 302 do CPC). No processo penal, ao contrário, porque dominado pelo conceito de verdade real, não haveria espaço para qualquer tipo de presunção dessa ordem.

Já vimos, de forma exaustiva, até, as razões que nos impedem de sequer cogitar da existência de uma verdade real. Mas é preciso dizer, ainda, que essa tentativa de justificar a ausência de presunções no processo penal com base na verdade real é sutilmente falaciosa. Com efeito, as presunções no processo penal não podem ser admitidas, tal e qual no processo civil, por duas razões básicas: os interesses discutidos no processo penal (liberdade, fundamentalmente) são indisponíveis, de forma que, permitir qualquer tipo de presunção sobre a verdade com base no comportamento do réu, autor, vítima, ou quem quer que seja, seria o mesmo que permitir a disponibilidade desses interesses, por uma via transversa; além disso, e justamente em função das preocupações com a proteção da liberdade, o acusado deve ser presumido inocente até o trânsito em julgado da sentença penal condenatória, e qualquer outra presunção deve ceder frente a essa regra.

O perigo, note-se bem, é que esse discurso da verdade real é frequentemente utilizado para fundamentar a relativização de certas garantias, como a que proíbe a utilização de provas obtidas por meios ilícitos. Digamos, por exemplo, que chegou ao conhecimento de um juiz a notícia de que o acusado realmente cometeu um crime bárbaro, mas essa informação veio através de uma escuta telefônica clandestina. Tudo bem, a prova foi obtida por meios ilícitos, mas, com base na verdade real...

É preciso lembrar, mais uma vez, que não há nada que nos imunize de cometer, eventualmente, um erro judiciário. Por mais provada que pareça a tese acusatória, será sempre possível suspeitar dela. Por mais fiel que o juiz seja às garantias processuais, a injustiça na decisão também pode acontecer. Jamais será possível ao juiz, por conseguinte, ter a certeza absoluta de que decidiu de forma acertada ao condenar ou absolver. A única certeza que pode ter, na verdade, porque isso depende dele, em cada ato do processo, é que todas as garantias processuais foram respeitadas, e aí, ainda que venha a cometer uma injustiça, ele (e o Estado) terá pelo menos a certeza de que o erro era realmente inevitável. 
É forçoso reconhecer, portanto, que também no processo penal a verdade possível é apenas a verdade processual, que está necessariamente comprometida com condições de convalidação, traduzidas em regras que disciplinam um método legal de comprovação processual.

Assim, falar de um modelo racional de investigação sobre a verdade fática implica falar de uma verdade processual, normatizada e estritamente vinculada à observância de certas garantias processuais. Essas garantias processuais, por seu turno, teriam como missões básicas, na lição de Ferrajoli: ${ }^{8}$ garantir a necessidade da prova ou verificação; garantir a possibilidade de contraprova, ou refutação; garantir a decisão imparcial e motivada por parte do juiz.

Mas, quais seriam exatamente essas garantias? De que maneira exatamente elas cumpririam essas tarefas? O conjunto dessas garantias compõe um sistema? Que lógica governaria esse sistema?

Parece claro, inicialmente, que a apresentação desses problemas fundamentais das garantias, nesses termos, supõe a adoção de uma estrutura de processo penal francamente orientado conforme o sistema acusatório, consagrado, inclusive, na cláusula constitucional que impõe o devido processo legal.

É preciso, portanto, conforme a lição de Prado,

"[...] um processo de partes, visto quer do ponto de vista estático, por meio da análise das funções significativamente designadas aos três principais sujeitos, quer do ponto de vista dinâmico, ou seja, pela observação do modo como relacionam-se juridicamente autor, réu, seu defensor e juiz no exercício das mencionadas funções". ${ }^{9}$

Assim, a presença ou a ausência das ditas garantias, num dado sistema processual penal, permite, por um lado, aferir o grau de limitação ou redução do chamado poder de disposição dos juízes, e, por outro lado, distinguir entre sistemas mais ou menos inquisitivos ou acusatórios. ${ }^{10}$

\section{Garantias, direito à prova e vedação às provas ilícitas.}

$\mathrm{Na}$ esteira do que dissemos acima, é possível, à luz das categorias tradicionais da Teoria do Processo Penal, compreender as garantias processuais, dentro de certos limi-

8 FERRAJOLI, L. Direito e razão, p. 119.

9 PRADO, Geraldo. Sistema acusatório, p. 114.

10 Para Juan Montero Aroca, a distinção entre sistema acusatório e inquisitivo já não faz nenhum sentido, posto que na verdade, só em relação ao primeiro seria possível falar de processo, propriamente. Observa esse autor: "El denominado proceso inquisitivo no fue y, obviamente, no puede ser, un verdadero proceso [...] El proceso acusatorio si es un verdadero proceso [...]" El derecho procesal en el siglo XX, p. 106. 
tes, como manifestações, aspectos, ou faculdades compreendidas pelo chamado direito a prova no processo penal. Parece claro, por outro lado, que a faculdade de provar, isto é, de tentar convencer o juiz da verdade fática, deve ser vista, necessariamente, como manifestação específica do direito de ação, de um lado, e do direito de defesa, do outro, tudo, aliás, em perfeita consonância com a ideia de um processo de tipo acusatório, em que todas as premissas (fáticas e jurídicas) que devam ser consideradas pelo juiz no momento de sua decisão sejam construídas dialeticamente pelas partes.

É preciso ter em mente, ainda, que, se prova é a comunicação que as partes estabelecem com o juiz para convencê-lo de suas verdades, então é natural que um direito à prova seja necessariamente decomposto em duas faculdades mais gerais: o direito de falar de um lado, isto é, o direito de introduzir elementos de prova no universo probatório; e o direito de ser ouvido, isto é, o direito a que os elementos de prova sejam avaliados e interpretados corretamente pelo juiz. Tem-se, assim, postos em outros termos, os clássicos problemas da admissibilidade e da valoração da prova, como são classicamente estudados pela doutrina processual. As garantias processuais, portanto, que devem dar conteúdo ao direito a prova, em toda a sua abrangência, dizem respeito, como veremos, a uma coisa ou outra, inevitavelmente.

A admissibilidade da prova, por outro lado, pode ser estudada sob suas perspectivas distintas. Primeiro, sob o prisma da produção, isto é, dos canais através dos quais se permite às partes introduzir informações no processo e das formalidades que precisam ser atendidas em cada hipótese, de acordo com cada tipo de procedimento estabelecido previamente em Lei. Trata-se, na verdade, das implicações, no campo específico da disciplina jurídica da prova, do princípio do devido processo legal em sentido restrito, ou, como querem alguns, do princípio do devido procedimento.

O que nos interessa, entretanto, no caso específico, são as formas como foram $o b$ tidas as informações pela parte, antes de levá-las ao processo, em face de uma eventual violação a normas de direito material ou princípios gerais do ordenamento. Veja-se, a esse respeito, a norma do art. 5ํ․, LVI da CF: são inadmissíveis no processo as provas obtidas por meios ilícitos.

Como bem registra Gomes Filho, trata-se de um vastíssimo campo “das proibições de prova relacionadas à tutela de valores estranhos à economia interna do processo [...]", ${ }^{11}$ que decorrem, na verdade, de uma ideia consagrada em nossa cultura jurídica, conforme a qual, mesmo para alcançar a verdade, o Estado, por meio da atividade jurisdicional, não pode atropelar outros valores acolhidos pela sociedade. ${ }^{12}$

\footnotetext{
11 Direito à prova no processo penal, p. 98.

12 Não iremos tratar, aqui, da exclusão de provas por motivos lógicos (relevância ou pertinência), posto que muito embora constituam o tema geral da admissibilidade das provas, não resultam, propriamente, de proibições embasadas em garantias contra o poder punitivo, e extrapolam, assim, aquilo que seria elemento específico, de uma dogmática garantista da prova penal. Na verdade, nem os sistemas de direito penal mínimo, tampouco os sistemas de direito penal máximo (os últimos principalmente) dispensam normas que visem evitar o dispêndio desnecessário de esforços do aparelho judicial na busca da verdade.
} 


\section{Ilicitude da prova, proteção à intimidade e sigilos constitucionais}

Tudo o que se disse acima constitui o pano de fundo teórico-crítico ao qual deve estar circunscrita a temática dos sigilos constitucionais, previstos no já mencionado art. $5^{\circ}$, XII, da CF.

Quem se der ao trabalho de pesquisar em obras monográficas, artigos e decisões de tribunais superiores, verá que existe ainda muita incerteza e instabilidade na aplicação do dispositivo acima citado e, o que é pior, uma tendência à construção de lugares comuns que abrem espaço para a atuação de um decisionismo judicial perigosíssimo e totalmente incompatível com as noções mais elementares de democracia.

Um dos vetores que contribui para a formação desse quadro, sem dúvida alguma, vem da própria estrutura sintática do texto constitucional. Isso porque, se o sigilo das comunicações telefônicas é o único que pode deixar de ser inviolável e pode ser quebrado para fins de investigação ou instrução criminal, na forma da Lei e mediante autorização judicial, então a consequência lógica que se impõe, lendo o dispositivo a contrario sensu, é que os demais sigilos (correspondência, dados e comunicações telegráficas) são absolutamente invioláveis, isto é, não poderão ser quebrados nem mesmo nas hipóteses e condições já mencionadas. ${ }^{13}$ Essa interpretação, contudo, tem sido frequentemente rechaçada, sob o argumento de que não há direito fundamental absoluto, um antigo dogma da doutrina constitucionalista.

Conforme a hipótese que sustentamos, existe aí, na verdade, uma série progressiva de falácias interpretativas que desafiam frontalmente o princípio da proporcionalidade e precisam ser urgentemente trazidas à luz. Para tanto, contudo, será necessário um breve cotejo entre as várias espécies de sigilo, a começar da quebra do sigilo das comunicações telefônicas, única autorizada expressamente pelo Constituinte.

\subsection{Sigilo das comunicações telefônicas}

A Lei n⿳o 9.296/96 foi criada para regulamentar o art. 5ํ, XII, da Constituição, estabelecendo os requisitos e o procedimento para as chamadas interceptações telefônicas. Assim, dispõe o art. $1^{\circ}$, da referida Lei que a interceptação telefônica será decretada "[...] para prova em investigação criminal e em instrução penal [...] pelo juiz competente para a ação principal". No parágrafo único desse artigo consta, ainda, que: "disposto nesta Lei aplica-se à interceptação do fluxo de comunicações em sistemas de informática e telemática".

$\mathrm{O}$ art. $2^{\circ}$, por seu turno, interpretado a contrario sensu, exige: (a) que haja indícios razoáveis da autoria ou participação em infração penal punida com reclusão; (b) que fique demonstrado que a prova não pode ser feita de outro modo; (c) que seja delimi-

13 Nesse sentido: GOMES FILHO, A. M. Op. cit., p. 123. 
tado o objeto da investigação e indicada, pelo menos, ou qualificada, quando possível, a pessoa investigada.

O art. 5, como se vê, estabelece que a interceptação "não poderá exceder o prazo de quinze dias, renovável por igual tempo uma vez comprovada a indispensabilidade do meio de prova".

Como sabemos, o próprio texto constitucional prevê a possibilidade de quebra do sigilo telefônico pelo juiz, o que nos obriga a aceitar a sua existência. Resta saber, contudo, dentro de que limites a Lei nº 9.296/96 é realmente compatível com a norma constitucional que pretendia regular e quais as consequências que podem surgir das eventuais incompatibilidades.

O art. $3^{\circ}$ da Lei $n^{\circ} 9.296 / 96$, como sabemos, permite que a medida seja decretada de ofício pelo juiz ou a requerimento do Ministério Público ou da autoridade policial. O citado dispositivo, segundo pensamos, viola frontalmente o princípio do devido processo legal, na medida em que, a um só tempo, contradiz as duas mais evidentes características do sistema acusatório de processo penal: juiz imparcial, e partes parciais, em igualdade de condições. Se a quebra do sigilo tem sido compreendida como medida jurisdicional cautelar, dentro de um modelo processual acusatório só poderia ser deferida a requerimento das partes, jamais de ofício ou por representação da autoridade policial (que não é parte, evidentemente).

Abstraído, contudo, o problema da decisão de ofício, há ainda outra questão relacionada à atuação do juiz na interceptação: mesmo nos casos em que a medida seja requerida pelo Ministério Público, o juiz que deferiu a quebra do sigilo não terá comprometida a sua imparcialidade para processar e julgar a causa? As coisas poderiam ser resolvidas, conforme a lição de Prado, ${ }^{14}$ se existisse no nosso ordenamento a figura do juiz de garantias, isto é, aquele com competência somente para decidir sobre medidas que importem em restrição de direitos fundamentais. O texto legal, todavia, reza que o juiz que deve decidir sobre a quebra é o juiz competente para a ação principal.

Por outro lado, não há nada que justifique que uma medida cautelar de obtenção de prova esteja disponível apenas para a acusação, e não para a defesa. Com efeito, os argumentos propostos em defesa dessa inaceitável unilateralidade não convencem. Chega-se a sustentar essa tese com fundamento na excepcionalidade própria de toda medida cautelar. A interceptação, assim, não poderia ser vulgarizada com a sua utilização indiscriminada. ${ }^{15}$ Há, contudo, uma indisfarçável falácia nesse raciocínio, já que a excepcionalidade, na verdade, deve decorrer do rigor do juiz em decidir sobre a necessidade da medida em cada caso e não exatamente do número de sujeitos processuais que, em tese, poderão requerê-la.

Ademais, a interceptação telefônica, por força do art. 1ำ da Lei respectiva, deve ser sigilosa, sobretudo em face do investigado, pois, do contrário, é claro que seria totalmente inócua como instrumento de investigação. $\mathrm{O}$ art. $5^{\circ}$, por outra senda, não

\footnotetext{
14 PRADO, Geraldo. Op. cit., p. 55.

15 GOMES, Luis Flávio; CERVINI, Raúl. Interceptação telefônica: Lei nº 9.296, de 24.07.96. São Paulo: Revista dos Tribunais, 1997, p. 121.
} 
obstante estabeleça um prazo de 15 dias para a duração da interceptação, permite a sua prorrogação, a critério do juiz, sem estabelecer qualquer limite, no particular. Trata-se, assim, de medida cautelar inaudita altera parte, ou seja, decretada sem ouvir a outra parte, e executada sem o seu conhecimento, e, como querem alguns, por tempo indeterminado (desde que sejam renovados os prazos pelo juiz). ${ }^{16}$ Não é possível deixar de ver nessas regras graves problemas, para não dizer violações a outros princípios, como o contraditório e a ampla defesa. Afinal, como o acusado poderá resistir e se opor à medida se dela não tem conhecimento? Como poderá fazer a crítica e a contraprova oportuna dos elementos colhidos durante a interceptação? A explicação normalmente apresentada pela doutrina não convence. Como regra, trabalha-se com o conceito de contraditório diferido ou postergado. Isto é, o controle sobre a legalidade da decisão que autorizou a medida, bem assim o acesso e a refutação das informações colhidas poderão ser feitos num momento posterior. Curiosamente, contudo, não se enfrenta uma questão crucial e aparentemente elementar: diante da gravidade das consequências de uma interceptação telefônica, será possível compatibilizar a ideia de contraditório diferido com a exigência de uma defesa ampla e efetiva? Como fiscalizar, por exemplo, no momento da realização da interceptação, a atuação dos agentes responsáveis pela realização da diligência? Como evitar que informações que não interessem ao acusador sejam omitidas? Como evitar edições comprometedoras?

Parece claro, desse modo, que a interceptação telefônica, da forma como está tratada pela legislação infraconstitucional, fere frontalmente inúmeros dispositivos da Constituição Federal. É preciso reconhecer que, mal ou bem, a medida está prevista na Constituição Federal, que deferiu à lei ordinária a tarefa de regulamentar o instituto. Mas isso não significa, absolutamente, que o constituinte emitiu uma espécie de cheque em branco. Antes, cabia ao legislador ordinário elaborar um diploma legal que tornasse a medida viável, mas sempre dentro dos limites impostos pelos princípios do Direito Processual Penal, inscritos na Constituição Federal. Se não é assim, é forçoso reconhecer que a norma constitucional que excepciona a proteção ao sigilo telefônico ainda não encontrou regulamentação adequada. Trata-se, pois, de norma válida e vigente, mas sem eficácia no sentido técnico.

Não se pode negar, entretanto, que referidas normas cumprem uma importante função de garantia ao restringir a medida, reservando-a a certas infrações penais (punidas com reclusão) e limitando-a somente àquela infração noticiada pelo requerente e às pessoas indicadas como supostos autores. Daí decorre, primeiro, que o encontro fortuito de informações sobre outros fatos ou sobre outras pessoas só pode ser aproveitado para infrações penais conexas à que se pretende investigar. ${ }^{17}$ Qualquer outro achado,

\footnotetext{
16 Nesse sentido, recente decisão do STJ, no RHC 13.274 RS.

17 Nesse sentido: GOMES, Luis Flávio; CERVINI, Raúl. Interceptação telefônica: Lei nº 9.296, de 24.07.96. São Paulo: Revista dos Tribunais, 1997, p. 192-195. Em sentido contrário, admitindo a utilização da intercepção para infrações não conexas, PRADO, Geraldo. Limite às interceptações telefônicas e a jurisprudência do Superior Tribunal de Justiça. Rio de Janeiro: Lumen Juris, 2005.
} 
portanto, deve ser entendido apenas como notícia de crime, imprestável para dar base a uma acusação, mas apta apenas a permitir que sejam realizadas outras investigações a partir dela. Ademais, as informações obtidas com a escuta telefônica não podem ser utilizadas como prova emprestada em outro processo - de natureza penal ou não penal. ${ }^{18}$ A regra do $\mathbb{S} 5^{\circ}$, contudo, tem sido interpretada pelos tribunais superiores de uma forma extremamente perigosa, tolerando a prorrogação sucessiva do prazo de 15 dias, independentemente de nova decisão judicial, o que acabou transformando o dispositivo em letra morta. Por fim, é preciso ter em mente que a regra do art. 1ํㅗ parágrafo único, ao estender a aplicação da Lei às comunicações estabelecidas através de sistemas de informática e telemática, para alguns, representa um excesso em relação ao que foi autorizado na Constituição. ${ }^{19}$

\subsection{Sigilo de dados e da correspondência}

Não há como iniciar esse tema sem voltar a discutir a natureza absoluta ou relativa dos demais sigilos constitucionais.

Constatamos, inicialmente, que a própria Constituição limita a possibilidade de quebra (dadas certas circunstâncias) ao sigilo das comunicações telefônicas, o que tornaria os outros absolutamente invioláveis. Contra esse caminho de interpretação, tem-se oposto que todo direito individual é relativo, inclusive aqueles previstos na Constituição e tidos como fundamentais - que, exatamente porque relativos, podem sofrer alguma restrição por parte da legislação infraconstitucional. Assim, a regra para essas informações (dados sensíveis) seria de fato o sigilo, que pode ser quebrado, dependendo, contudo, de expressa previsão legal e autorização judicial. É o que ocorre com o caso específico do sigilo bancário, regulado expressamente pelo art. $1^{\circ}, \mathbb{S} 4^{\circ}$ da Lei Complementar $\mathrm{n}^{\circ} 105,{ }^{20}$ e com o sigilo fiscal, nos termos do art. 198, $\mathbb{S} 1^{\circ}$, II, do CTN. Mais recentemente, foi sancionada a Lei $n^{\circ}$ 12.965/14 (Marco Civil da Internet), que regulamenta o sigilo de dados na internet na forma seguinte:

18 GOMES, Luis Flávio; CERVINI, Raúl. Interceptação telefônica: Lei nº 9.296, de 24.07.96. São Paulo: Revista dos Tribunais, 1997, p. 119.

19 Para Gomes Filho, A. M., "a inconstitucionalidade é manifesta, posto que o legislador teria excedido à autorização constitucional, que só permite a quebra do sigilo das comunicações telefônicas”. Op. cit., p. 125. Já para Luiz Flávio Gomes, "a extensão seria condizente com a ratio legis que inspirou a própria norma constitucional, e com a própria evolução das tecnologias de comunicação”. Interceptações telefônicas, p. 167-171.

20 Conforme dispõe o art. $1^{\circ}, \mathbb{S} 4^{\stackrel{\circ}{ }}$, da referida Lei, in verbis: Art. $1^{\circ}$ [...] $\mathbb{S} 4^{\circ}$ A quebra de sigilo poderá ser decretada, quando necessária para apuração de ocorrência de qualquer ilícito, em qualquer fase do inquérito ou do processo judicial, e especialmente nos seguintes crimes: I - de terrorismo; II - de tráfico ilícito de substâncias entorpecentes ou drogas afins; III - de contrabando ou tráfico de armas, munições ou material destinado à sua produção; IV - extorsão mediante sequestro; V - contra o sistema financeiro nacional; VI - contra a Administração Pública; VII - contra a ordem tributária e a previdência social; VIII - lavagem de dinheiro ou ocultação de bens. Diretos e valores; IX - praticado por organização criminosa. 
"Art. 22. A parte interessada poderá, com o propósito de formar conjunto probatório em processo judicial cível ou penal, em caráter incidental ou autônomo, requerer ao juiz que ordene ao responsável pela guarda o fornecimento de registros de conexão ou de registros de acesso a aplicações de internet.

Parágrafo único. Sem prejuízo dos demais requisitos legais, o requerimento deverá conter, sob pena de inadmissibilidade:

I - fundados indícios da ocorrência do ilícito;

II - justificativa motivada da utilidade dos registros solicitados para fins de investigação ou instrução probatória; e

III - período ao qual se referem os registros.

Art. 23. Cabe ao juiz tomar as providências necessárias à garantia do sigilo das informações recebidas e à preservação da intimidade, da vida privada, da honra e da imagem do usuário, podendo determinar segredo de justiça, inclusive quanto aos pedidos de guarda de registro".

Mas há mesmo quem sustente que a exigência de previsão legal estaria satisfeita, de forma genérica, por conta dos dispositivos inseridos na legislação institucional do MP que lhe asseguram a prerrogativa de requisitar informações de instituições públicas e privadas. ${ }^{21}$

No caso do sigilo epistolar, entretanto, a ameaça à intimidade e à vida privada vai ainda mais longe, uma vez que, conforme assentado pela jurisprudência nesses casos, não se exige nem mesmo previsão legal (que efetivamente não existe) ou autorização judicial. Nos termos do decisum que coletamos apenas como amostra:

"A administração penitenciária, com fundamento em razões de segurança pública, de disciplina prisional ou de preservação de ordem jurídica, pode, sempre excepcionalmente, e desde que respeitada a norma inscrita no art. 41, parágrafo único, da Lei 7.210/84, proceder à interceptação da correspondência remetida pelos sentenciados, eis que a cláusula tutelar da inviolabilidade do sigilo epistolar não pode constituir instrumento de salvaguarda de práticas ilícitas." 22

\subsection{Sigilos e proporcionalidade}

Em vista desse cenário, a hipótese que sustentamos é de que o tratamento que se tem dispensado aos sigilos constitucionais, por parte da doutrina e jurisprudência dominantes, desafia o chamado princípio da proporcionalidade em pelo menos dois níveis superpostos. Vejamos.

21 GOMES, Luis Flávio; CERVINI, Raúl. Op. cit., p. 103.

22 HC 70.814-5-SP. 
Hoje largamente aceito, o princípio tem sido pela doutrina constitucionalista como sendo uma espécie de baliza fundamental a ser observada pelos que exercem o poder, exigindo uma relação adequada entre um ou vários fins determinados e os meios com que são perseguidos pelos órgãos do Estado.

Segundo Bonavides, citando Muller:23

"Nesta última acepção [...] há violação do princípio da proporcionalidade, com ocorrência de arbítrio, toda vez que os meios destinados a realizar um fim não são por si mesmo apropriados e/ou quando a desproporção entre meios e fins é particularmente evidente." 24

Registre-se, ademais, que o princípio da proporcionalidade encontra-se indubitavelmente positivado no nosso direito constitucional, visto que,

"Embora não haja sido ainda formulado como 'norma jurídica global', flui do espírito que anima em toda a sua extensão e profundidade o $\mathbb{S} 2^{\circ}$ do art. $5^{\circ}$, o qual abrange a parte não escrita ou não expressa dos direitos e garantias da constituição [...]."25

Se de um lado parece evidente que a temática das proibições de prova se funda na necessidade de assegurar a mais correta reconstrução dos fatos, de outro ressalta a ideia de que a atividade probatória deve ser limitada, em face da tutela conferida pelo ordenamento a outros valores que, à luz do princípio da proporcionalidade, se sobrepõem à busca da verdade judicial. ${ }^{26}$

É exatamente aqui, note-se bem, que começam as distorções observáveis no tratamento conferido aos sigilos. Isso por que determinados setores da doutrina e da jurisprudência têm extraído dessa verdade, aqui e ali, conclusões extremamente perigosas. É que, se a opção entre a busca da verdade e a defesa das garantias individuais se traduz numa questão de proporcionalidade, em alguns casos seria mais conveniente sacrificar o direito individual em favor de um interesse social mais elevado. Assim, na hipótese de prova ilícita de um crime de furto (art. 155 do $\mathrm{CP}$ ), por exemplo, estaria em jogo, de um lado a intimidade e, do outro, o patrimônio, devendo prevalecer a proteção à intimidade. Num caso de homicídio, todavia, deveria prevalecer o bem jurídico vida e, dessa forma, a prova ilícita poderia ser aceita - já que a vida, sem dúvida, é mais preciosa do que a intimidade de quem quer que seja.

O que percebemos, entretanto, é que por trás desse raciocínio existe uma tentativa equivocada de distorcer o conteúdo do princípio da proporcionalidade, uma verdadeira

23 MULLER, Pierre, Zeitschrift für Recht, Band 97, 1978, Basel, p. 531, apud BONAVIDES, Paulo, Curso de direito constitucional, p. 457.

24 BONAVIDES. Op. cit., p. 357. Na mesma linha, CANOTILHO. Op. cit., p. 262-261.

25 BONAVIDES, p. 396.

26 GOMES FILHO, A. M. Op. cit., p. 124. 
porta larga, segundo a lição de Gomes Filho, ${ }^{27}$ para a banalização dos direitos e garantias individuais e um atentado à presunção de inocência. Primeiro porque, para proceder à comparação dos interesses em conflito, o juiz fará, necessariamente, um prejulgamento (condenatório) sobre o fato atribuído ao acusado: para dizer que estão em jogo a vida e a intimidade, no exemplo acima citado, o juiz tem que estar previamente convencido de que houve de fato o homicídio e de que o acusado foi o seu autor. Depois, porque a própria comparação que se pretende fazer nesses casos, entre a privacidade e o bem jurídico penalmente tutelado pela norma jurídica, repousa numa premissa falsa, uma vez que, cometido o delito, já não haverá bem jurídico algum a proteger. O conflito que pode existir, a bem da verdade, é entre a intimidade do acusado e o interesse do Estado em aplicar uma sanção. Por fim, após o estudo que fizemos sobre a verdade processual, podemos afirmar que a estrita observância das garantias processuais constitui um verdadeiro pressuposto do conceito de verdade, e não é possível falar de verdade fora desses limites.

É exatamente assim, note-se, que se tem procedido em relação ao sigilo da correspondência.

Mas existe ainda um outro problema: ainda que se admita que o sigilos da correspondência e de dados não são absolutos, o mínimo que se podia esperar, nesses casos, é que a quebra estivesse vinculada e dependesse da demonstração de requisitos pelo menos tão rígidos quanto àqueles previstos para a quebra do sigilo telefônico.

De fato, a Lei no 9.296/96, já referida, estabelece uma série de requisitos para que a quebra do sigilo telefônico, dentre os quais, como veremos, que a informação desejada não possa ser obtida pelos meios ordinários. Além disso, há ainda uma série de limitações temporais e materiais para a utilização da informação, bem como a previsão de sanções para o uso indevido da informação que vier a ser colhida. Veja-se, assim, que interessante paradoxo: para o tipo de sigilo que o constituinte julgou conveniente excepcionar, a lei infraconstitucional tratou de criar algumas garantias mínimas, ao passo que, para o sigilo de dados, que a Constituição não excepcionou (e que tem estado no centro das preocupações e dos debates contemporâneos em torno da proteção à intimidade e da vida privada), o que se vê é uma inaceitável tolerância, sempre sob o argumento - falacioso, no caso - que invoca a natureza relativa dos direitos fundamentais.

Tal circunstância, aliás, torna a o controle jurisdicional sobre tais medidas totalmente estéril. No caso do sigilo bancário, por exemplo, nos termos da LC nº 105, para que isso seja possível basta que seja necessária para apuração de ocorrência de qualquer ilícito, em qualquer fase do inquérito ou do processo judicial, especialmente em certos crimes como terrorismo, tráfico, etc. Como se manifesta aqui o fumus boni iuris? E o que dizer do periculum in mora? Será possível, de fato, relativizar a vedação constitucional à quebra do sigilo de dados sob o singelo argumento de que isto é necessário para investigar qualquer tipo de crime? Nos casos de quebra de sigilo fiscal, aliás, a situação é ainda

27 Ibidem, p. 105-106. 
mais complicada, uma vez que a quebra pode ser autorizada desde que haja "requisição da autoridade judiciária no interesse da justiça", nos termos do art. 198, $\mathbb{S} 1^{\circ}$, I, do CTN.

Por tudo isso, parece mesmo haver uma violação do princípio da proporcionalidade em outro nível, na medida em que se permite que os sigilos ditos "absolutos" podem ser quebrados, em tese, conforme requisitos muito mais "frouxos' do que o sigilo considerado "relativo".

\section{Conclusões}

a) Doutrina e jurisprudência dominantes, de um modo geral, entendem cabível a quebra do sigilo de dados e da correspondência, a despeito do que dispõe o art. 5, XII, da CF.

b) O argumento normalmente utilizado para tanto é recolhido da doutrina dos direitos fundamentais, segundo a qual não existe direito fundamental absoluto, de forma que a, a depender das circunstâncias, tendo em vista a natureza dos interesses em conflito, podem sofrer restrições, desde que haja previsão legal para tanto, e autorização judicial.

c) No caso do sigilo da correspondência, entretanto, nem mesmo esse argumento acode a quebra do sigilo, já que não existe previsão legal expressa nesse sentido.

d) O argumento parece ignorar, ainda, que a própria garantia da vedação às provas ilícitas é o produto de uma ponderação do próprio constituinte entre o direito do Estado de investigar crimes e outros valores que a própria ordem constitucional protege, tal como a intimidade e a vida privada do indivíduo.

e) Além disso, ao propor a ponderação entre a intimidade e o bem jurídico supostamente violado pelo acusado na prática delitiva, viola-se o princípio da presunção ou estado de inocência. Condena-se antes, para considerar a prova lícita, e não o contrário, como impõe a noção ais elementar de devido processo legal.

f) Por fim, tem-se uma segunda distorção do princípio da proporcionalidade, uma vez que os requisitos para a quebra de sigilos "absolutos" acabam bem mais "frouxos" do que aqueles estabelecidos para a quebra do sigilo telefônico.

\section{Referências bibliográficas}

ABBAGNANO, Nicola. Dicionário de filosofia. 3. ed. São Paulo: Martins Fontes, 1999.

BARATTA, Alessandro. Criminologia crítica e crítica do direito penal: introdução à sociologia do direito penal. Tradução de Juarez Cirino dos Santos. Rio de Janeiro: Revan, 1997. 
BONAVIDES, Paulo. Curso de direito constitucional. 11. ed. São Paulo: Malheiros, 2001.

CANOTILHO, Jose Joaquim Gomes. Direito constitucional e teoria da constituição. 2. ed. Coimbra: Almedina, 1998.

DUCLERC, Elmir. Prova penal e garantismo: uma investigação crítica sobre a verdade fática construída através do processo. Rio de Janeiro: Lumen Juris, 2004.

FERRAJOLI, Luigi. Direito e razão: teoria do garantismo penal. 3. ed. Madrid: Trotta, 1998.

FOUCAULT, Michel. A verdade e as formas jurídicas. 2. ed. Tradução de Roberto Cabral de Melo Machado e Eduardo Jardim Moraes. Rio de Janeiro: Nau Ed., 1999.

. Vigiar e punir. Tradução de Raquel Ramalhete. 19. ed. Petrópolis: Vozes, 1999.

GOMES FILHO, Antonio Magalhães. Direito à prova no processo penal. São Paulo: Revista dos Tribunais, 1997.

GOMES, Luis Flávio; CERVINI, Raúl. Interceptação telefônica: Lei nº 9.296, de 24.7.96. São Paulo: Revista dos Tribunais, 1997.

PRADO, Geraldo. Limite às interceptações telefônicas e a jurisprudência do Superior Tribunal de Justiça. Rio de Janeiro: Lumen Juris, 2005.

. Sistema acusatório: a conformidade constitucional das leis processuais penais. 3 . ed. Rio de Janeiro: Lumen Juris, 2005.

MIAILLE, Michel. Introdução crítica ao direito. 2. ed. Lisboa: Ed. Estampa, 1989.

MONTERO AROCA, Juan. El derecho procesal en el siglo XX.Valencia: Tirant lo Blanch, $2000.142 \mathrm{p}$.

ZAFFARONI, Eugenio Raúl. Em busca das penas perdidas: a perda de legitimidade do sistema penal. Tradução de Vania Romano Pedrosa e Amir Lopez da Conceição. Rio de Janeiro: Revan, 1989.

\section{Como citar este artigo:}

DUCLERC, Elmir. Sigilos constitucionais, prova ilícita e proporcionalidade. Revista Brasileira de Direito Processual Penal, Porto Alegre, vol. 1, n. 1, p. 185-201, 2015. http://dx.doi.org/10.22197/ rbdpp.v1i1.10 